\title{
Sclerosis multiplex a közép-magyarországi régióban: a helyi adatbázisfejlesztés tapasztalatai és jövőbeli lehetőségei
}

\author{
Iljicsov Anna dr. ${ }^{1}$ - Simó Magdolna dr. ${ }^{1}$ - Tegze Nárcisz dr. ${ }^{1}$ \\ Szócska Miklós dr. ${ }^{2}$. Mátyus Péter dr. ${ }^{2}$. Bereczki Dániel dr. ${ }^{1}$ \\ ${ }^{1}$ Semmelweis Egyetem, Általános Orvostudományi Kar, Neurológiai Klinika, Budapest \\ ${ }^{2}$ Semmelweis Egyetem, Egészségügyi Közszolgálati Kar, Digitális Egészségtudományi Intézet, Budapest
}

\begin{abstract}
Bevezetés: A rutin-betegellátás során keletkező adatok többféle digitális és papíralapú rendszerben jönnek létre, egy adott beteg gondozása során előkeresésük nehézkes. A sclerosis multiplex (SM) a fiatalkorban jelentkező leggyakoribb neurológiai betegség, jelentős egészségügyi és gazdasági következményekkel.

Célkitüzés: Célunk egy jól használható, kellően részletes adatbázis létrehozása, mely gyorsan hozzáférhetővé teszi a SM-beteg adatainak áttekintését, rögzítését és elemzését. Helyi regiszterünk létrehozásának tapasztalatai alapján dolgozzuk ki egy korszerú adatbázis modelljét.

Módszer: Az adatbázis alapját Excel-programban hoztuk létre, majd a nemzetközileg is használt iMed-rendszerben dolgoztunk. A regiszterben az alapadatok mellett rögzítettük a megjelenéseket, a relapsusokat, a kíséró betegségeket, az MRI, liquor-, kiváltottválasz- és egyéb laboratóriumi vizsgálatok leletét, a gyógyszeres és nem gyógyszeres kezeléseket.

Eredmények: Az adatbázis jelenleg 316 beteg adatát tartalmazza. MRI a betegek 96\%-ánál, liquorvizsgálat 45\%-nál történt. A SM-altípusok között a betegség kezdetekor a primer progresszív kórforma aránya 9\%. A kórlefolyás során immunmoduláns kezelésben a betegek $82 \%$-a részesült.

Következtetés: Az adatbevitel jelenlegi „hagyományos” módszere időigényes, a manuális adatbevitel és a PDF formátumban történő adatexport (leletek) a mai informatikai lehetőségek mellett elavultak. A korszerú és mind klinikai, mind kutatási célokra alkalmazható, helyi betegségspecifikus adatbázis folyamatos és nagyrészt automatikus adatbevitelt igényel. Ehhez elvárás az egységes dokumentációs nyelv és struktúra kialakítása és a különböző digitális rendszerekben rendelkezésre álló információk automatizált átemelése. A mindezt teljesítő leendő regiszter múködési modelljét mutatjuk be, amely egy egészségügyi adattóra épül.
\end{abstract}

Orv Hetil. 2019; 160(4): 131-137.

Kulcsszavak: betegregiszter, manuális adatrögzítés, automatizált adatbevitel, adattó

\section{Multiple sclerosis in central Hungary: experiences and future possibilities of developing a local database}

Introduction: Data during routine patient care are created in multiple digital and paper-based hardcopy systems, therefore their retrieval is cumbersome in the follow-up of patients. Multiple sclerosis is the most prevalent neurological disorder in the young age, with major consequences on health and socio-economic status.

Aim: We set forth to create a user-friendly, detailed local database where it is easy to access, register and analyze data. Based on our experiences during building this registry, we develop the model of a modern type of database.

Method: First we established a local registry in Excel, then data were transferred to the worldwide used iMed system. Separate pages were used to register basic data, follow-up visits, relapses, accompanying diseases, results of neuroimaging, cerebrospinal fluid, evoked response and other tests, pharmacological and non-pharmacological treatments. Results: The database currently contains data of 316 patients. MRI was performed in 96\%, cerebrospinal fluid examination in $45 \%$ of the patients. The rate of primary progressive disease at disease onset is $9 \%$. Disease modifying treatments were applied in $82 \%$ of the patients. 
Conclusion: The traditional manual data entry and data export in PDF format is obsolete and time-consuming. The development of local disease-specific databases appropriate for clinical and research purposes requires continuous and mostly automatic data entry. In future local registries the establishment of uniform documentational language and structure, and automatic transfer of information among different digital systems are required. We present the model of such a registry, which is based on a healthcare data lake.

Keywords: patient registry, manual data entry, automatized data entry, data lake

Iljicsov A, Simó M, Tegze N, Szócska M, Mátyus P, Bereczki D. [Multiple sclerosis in central Hungary: experiences and future possibilities of developing a local database]. Orv Hetil. 2019; 160(4): 131-137.

(Beérkezett: 2018. augusztus 8.; elfogadva: 2018. szeptember 20.)

\begin{abstract}
Rövidítések
BNO = betegségek nemzetközi osztályozása; EDSS = $($ Expanded Disability Status Scale) Bővített Rokkantsági Állapot Skála; eMedSol = (e-MedSolution) kórházi információs rendszer; EUReMS $=($ European Register for Multiple Sclerosis $)$ Európai SM Regiszter; GDPR $=($ General Data Protection Regulation) európai általános adatvédelmi rendelet/szabályzat; GLIMS $=($ General Laboratory Information Management System) Általános Laboratóriumi Információkezelő Rendszer; $\mathrm{iMED}=($ Innovation Medicine Program $)$ Innovációs Orvostudományi Program; MSBase $=($ multiple sclerosis base $)$ sclerosis multiplex bázis; $\mathrm{MRI}=$ (magnetic resonance imaging $)$ mágnesesrezonancia-képalkotás; SM/MS = (multiple sclerosis) sclerosis multiplex; SWOT $=$ (strengths, weaknesses, opportunities, threats) erősségek, gyengeségek, lehetőségek, veszélyeztető tényezők; TUKEB = Tudományos és Kutatásetikai Bizottság
\end{abstract}

A rokkantság hátterében a leggyakrabban idegrendszeri betegségek állnak, és ezek a kórképek a második leggyakoribb halálokként szerepelnek, világszerte a halálesetek egyhatodát okozva [1]. Gustavsson és mtsai szisztematikus összefoglalója a magyarországi sclerosis multiplexes (SM) betegek számát 6200-ra becsüli, és Magyarországon a vizsgált 12 idegrendszeri betegségcsoport közül az egy betegre jutó költséget a SM-betegeknél becsülik a legnagyobbra [2]. Számos országos és nemzetközi SMadatbázis létezik [3]. Hazánkban a sclerosis multiplexes betegek ellátásának szervezése 31 SM-centrumban történik. A centrumok egyrészt helyi adatbázisokat hoznak létre saját betegeik követése céljából, másrészt jelenleg zajlik az egységes országos SM-regiszter kiépítése [4]. Ennek hiányában egyelőre nem ismert hazánkban például sem a SM-betegséggel élők pontos száma, sem ellátásuk direkt és indirekt költsége. Az előbbire Csongrád megyei felmérés $[5,6]$ során számolt prevalencia $(83,7 / 100000)$ alapján következtethetünk extrapolációval, az utóbbit illetôen pedig kérdő́ives felmérés készült 2009-ben [7]. Többek között e kérdésekre is választ adhat egy részletes, országos SM-regiszter. Ennek kiépítésén túl fontos lenne nemzetközi SM-regiszterekhez tör- ténő csatlakozás, hogy a magyarországi adatok közvetlenül is integrálódhassanak a nemzetközi kutatásokba.

A Semmelweis Egyetem Neurológiai Klinikáján a SMcentrum három szakorvosa együtt körülbelül négyszáz beteget gondoz demyelinisatiós központi idegrendszeri kórkép miatt. E betegek egy része, betegségük stádiumától függően, csak évente egyszer vagy még ritkábban jelenik meg ambuláns vizsgálaton, míg az immunmoduláns kezelésben részesülő́k legalább háromhavonta jönnek kontrollvizsgálatra.

A rutin-betegellátás során egy betegről is számos adat (többek között klinikai, laboratóriumi, képalkotó) keletkezik, amelyek archiválása egyrészt jogszabályi elő́rás, másrészt feldolgozásukkal orvostudományi, epidemiológiai, egészséggazdasági kérdésekre kaphatunk választ, így az ilyen adatbázisok és regiszterek jelentős erőforrást képviselnek. A feldolgozás előfeltétele azonban az adatok strukturált rögzítése és naprakész frissítése.

Jelen munkánkban bemutatjuk egy helyi betegregiszter kialakítását és annak nehézségeit. Összehasonlítjuk továbbá a jelenleg szokásosan alkalmazott betegségspecifikus adatbázis-fejlesztés hagyományos lépéseit egy informatikai lehetôségeket sokkal jobban kihasználó, részben automatizált, korszerú adatbázis modelljével. Ez utóbbi fejlesztése során a távlati cél olyan informatikai rendszer felépítése, melyben a rutin-betegellátás során a helyi digitális betegnyilvántartási informatikai rendszerben képződő adatok intézményi szintû „adattóba” kerülnek, ahonnan egyszerúen átemelhetők vagy automatikusan átkerülnek a betegségspecifikus helyi regiszterbe.

\section{Betegek és módszer}

\section{Betegek}

A Semmelweis Egyetem Neurológiai Klinikáján a helyi adatbázis létrehozására egy rendszeres gondozásban részesülő betegcsoportot választottunk ki, akik SM miatt kerültek a látóterünkbe az elmúlt tíz év során. Mivel e kórkép ellátása országosan centrumokba szervezett, a Klinika Neuroimmunológiai Szakrendelésére Budapest 
és Pest megye egészéből járnak betegek. E betegség jelen ismereteink szerint nem gyógyítható, azonban a páciensek egy csoportjának tartós gyógyszeres kezelés javasolt, így ez évekig-évtizedekig tartó gondozást és rendszeres ambuláns vizsgálatot igényel - emiatt egy személy adatainak változásáról hosszmetszeti képet kaphatunk.

\section{Informatikai háttér}

A Semmelweis Egyetemen a betegellátás informatikai és adminisztratív hátterét a MedSol, a Neurológiai Klinikán ezen belül az eMedSol nyújtja, a belépés egyedi jelszóval védett. Az orvos-beteg találkozóról készült ambulánslap vagy zárójelentés PDF formátumban kerül archiválásra és kereshető vissza. Mind az ambuláns, mind a fekvőbeteg-esethez a nemzetközi kódokat használva rögzítjük a betegségnek, állapotnak megfelelő BNO-kódot. Technikai könnyebbséget jelent pácienseink visszakeresésében az informatikai rendszerből, hogy a SM-hez egyetlen BNO-kód tartozik (G35H0). Az eMedSol segítségével lehet vizsgálatokat (labor, MR, egyéb képalkotók, konzíliumok) rendelni, és ezek eredménye (lelet) a kezelőorvos számára PDF-ben jelenik majd meg.

Az Egyetemen belül készült laborvizsgálatok döntó részét a Laboratóriumi Medicina Intézet végzi el. A vizsgálatok elsődleges eredményei külön informatikai rendszerben (GLIMS) jelennek meg, amelyek másodlagosan, PDF formátumban kerülnek át a MedSolba. A Neurológiai Klinika liquorlaborjában készül a gerincvíz elemzése. $\mathrm{Az}$ eredményeket évtizedekig papíralapon, az utóbbi években már elektronikusan archiválják.

Az Egyetemen készült képalkotó vizsgálatok (köztük az MR) képanyaga egy közös, webalapú rendszeren megtekinthető (jelszóval védett hozzáféréssel), azonban a MedSolba csak az írásos lelet kerül (PDF formátumban), amely lényegesen kevesebb információt tartalmaz. A képanyag közvetlen feldolgozásához, elemzéséhez általában speciális és drága szoftverek nyújtanak segítséget a radiológusoknak és kutatóknak.

\section{Az adatbázis-fejlesztés módszere}

Az adatbázis fejlesztése során első lépésben, korábbi tapasztalataink alapján, az iMed-rendszerre esett a választás. Ennek előnyei, hogy ingyenesen elérhető és frissíthető, felhasználóbarát és grafikus megjelenítést ad az egyes betegek kórtörténetéről. A hatékony adatbevitel érdekében az iMed-szoftvert az MSBase Alapítvány honlapjáról 3 különböző klinikai számítógépre telepítettük. Az adatok biztonságát jelszavas belépés segíti. A program az adott számítógépen hoz létre egy könyvtárat, és tárolja a bevitt adatokat - ennek hátránya, hogy hardverprobléma esetén ezen adatok elveszhetnek. A rögzített adatok anonimizáltan, Excel-formátumba exportálhatók. Emellett lehetőség van arra, hogy az adatokat, szintén névtelenül, az MSBase webes felületének segítségével nemzetközi adatbázisba feltöltsük.

Az iMed-program segítségével egy beteghez rögzíthetők többek között az alapvető szociográfiai jellemzők (családi helyzet, származási ország, lakhely), a kísérő betegségek és az ezekre szedett gyógyszerek, a terhességek időpontja és kimenetele, a fizikális vizsgálat eredménye (testmagasság, testsúly, vérnyomás, pulzus), a sclerosis multiplex tüneteinek kezdete és azok időbeli alakulása (például relapsusok, EDSS-érték), az elvégzett eszközös vizsgálatok időpontja és eredményei (MR-, liquor-, elektrofiziológiai vizsgálatok, laborvizsgálatok), az alkalmazott kezelések (hatóanyag, időpont, dózis), azok esetleges mellékhatásai, az ambuláns vizitek és kórházi bennfekvések időpontja.

Az adatbázis kialakításakor a jelenlegi fázisban nem törekedtünk teljességre, hanem kiválasztottunk néhány releváns adatot (tünetkezdet, relapsusok, kísérő betegségek, MR-vizsgálatok, liquorvizsgálat, elektrofiziológiai vizsgálat, SM-terápia, ambuláns és fekvő esetekhez tartozó EDSS-érték), amelyeket minden beteghez regisztráltunk. A többi, rendelkezésre álló információval az adatbázis a későbbiekben tetszőlegesen bővíthető.

A rutin-betegellátásban alkalmazott betegdokumentációs rendszerben (MedSol) archivált klinikai, radiológiai és laborleletek, továbbá a liquorvizsgálat leletei jelenleg egymással automatikusan nem egyesíthető formában állnak rendelkezésre. Ezeket tehát manuálisan, a MedSolban archivált PDF-dokumentumokból kell visszakeresni és átvinni az iMed-formátumba.

\section{Az adatbázis-fejlesztés modellje}

Az MSBase nemzetközi hálózathoz már korábban regisztráltuk a Neurológiai Klinika SM-centrumát, így a honlapjukra belépve a szükséges szoftvert (iMed) ingyenesen telepíteni tudtuk. Az iMed angol nyelvú, és bár felhasználóbarát a megjelenítése, a helyes adatrögzítés módját meg kell tanulni. Az eMedSol megnyitásával párhuzamosan az iMed-szoftvert is megnyitottuk, és elöször a MedSol-ból kerestük ki a listánkon szereplő beteget. A beteg MedSol-ban fellelhető ambulánslapjait és zárójelentéseit, valamint vizsgálati leleteit egyenként megnyitva jutottunk az archivált PDF formátumú adatforráshoz. Ezekból a szövegekból kellett kikeresni a releváns információkat, majd ezeket az iMed formátumára módosítva ott manuálisan rögzíteni. Nyilvánvaló módon ez időigényes és nem automatizált folyamat, amelyet tovább bonyolít, hogy sem a leleteknek, sem az ambulánslapoknak nem egységes a formátuma, illetve néha a keresett adat hiányzik (például a beteg aktuális neurológiai állapotát tükröző EDSS-érték, amelyet azonban a részletes statusból utólag kell kiszámolni; vagy a koponyaMR-en látható T2-laesiók pontos száma stb.). A liquorvizsgálat eredménye vagy korábban rögzítésre került a szöveges MedSol-dokumentációban, és így onnan átvehető, vagy a papíralapú archívumunkból kellett kikeresni 
és onnan bevinni az iMed-be. Rendszeresen szembesültünk azzal, hogy bár bizonyos adatokról tudjuk, hogy léteznek (például MR-vizsgálat készült), azok részletei nem állnak rendelkezésre a MedSol-dokumentációban. Ez elsősorban az Egyetemen kívül készült vizsgálatok (MR, labor) eredményeire vonatkozik, amelyek a beteg tulajdonát képezik, és annak teljes körü átemelése például egy ambulánslapra nem oldható meg automatikusan (csak kézzel beírva). Az adatforgalom folyamatábráját az 1. ábrán foglaljuk össze.

Az adatbázis kialakítása a Semmelweis Egyetem Etikai Bizottságának engedélyével történt (a TUKEB-engedély száma: 229-2017).

\section{Eredmények}

\section{A helyi regiszterben szereplö adatok áttekintése}

Kellően részletes, illetve friss adatokra törekedve, az adatbázishoz a Neuroimmunológiai Szakrendelésen az elmúlt 10 évben SM miatt vizsgált betegek közül csak azokat vettük figyelembe, akik legalább három alkalommal megjelentek, és ebből legalább egyszer az elmúlt 5 év során. Közülük is csak $80 \%$ esetében teljesült az, hogy évente legalább egyszer kontollra jöttek, a többiek neurológiai állapota feltételezhetően vagy „túl jó” ahhoz, hogy indíttatást érezzenek jelentkezni, vagy „túl rossz”

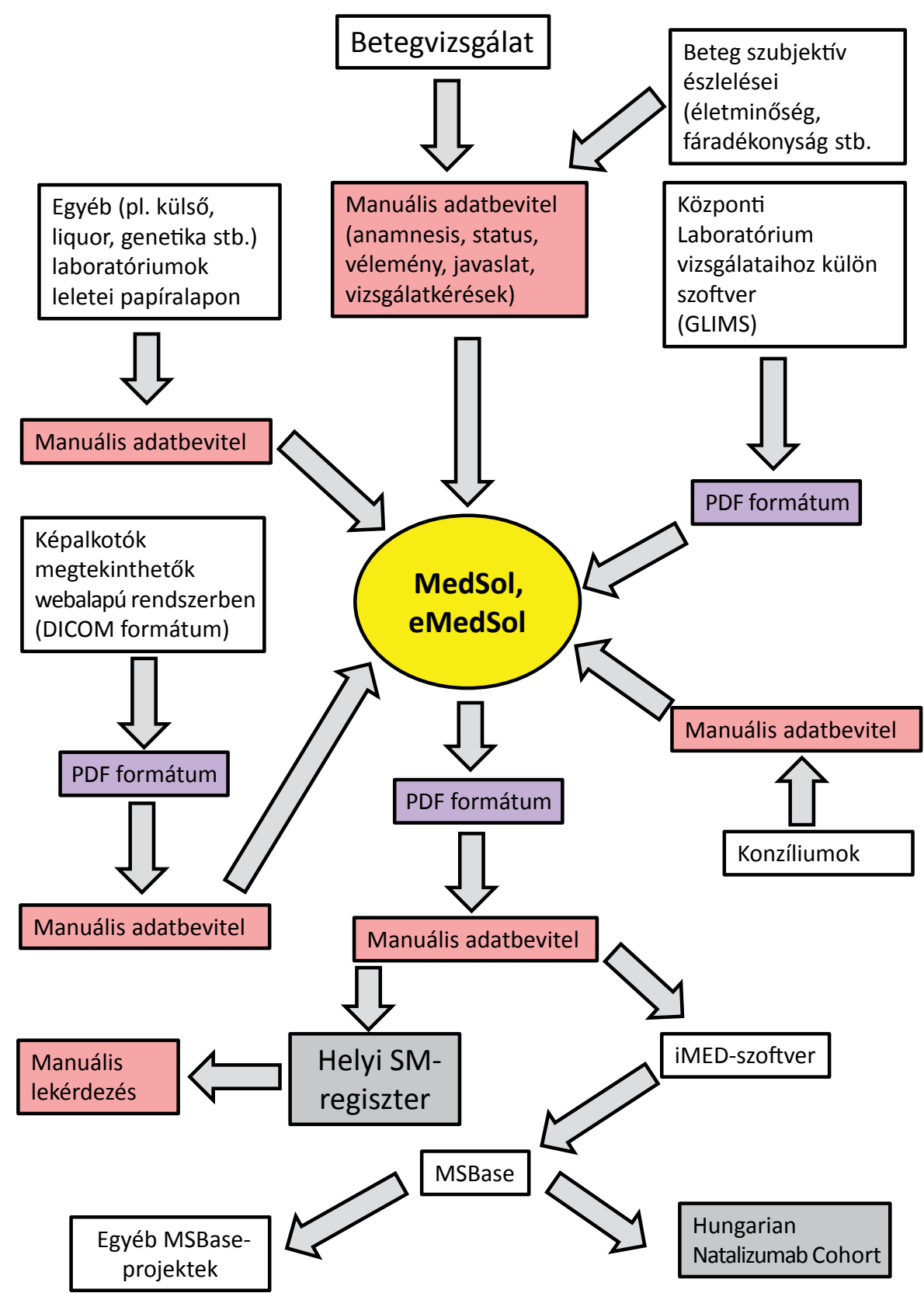

1. ábra $\mid$ A „hagyományos” helyi SM-regiszter folyamatábrája. Jellegzetes a különféle szoftverek alkalmazása, a PDF formátumban történő adatforgalom, a jelentős humánerőforrás-szükséglet és az időigényes manuális adatbevitel 
ahhoz, hogy fizikailag eljussanak a rendelésre. Az adatbázisban jelenleg 316 SM-beteg adata elemezhető. A modellhez tervezett és a ténylegesen rendelkezésre álló adatokat az 1. táblázat foglalja össze, a betegcsoport jellemzőit a 2. táblázatban mutatjuk be.

Betegeink között a nők száma jelentősen nagyobb. Az átlagos betegségtartam 13 év. A betegségkezdetról 262 beteg esetében volt megbízható információnk, ez alapján a primer progresszív kórforma aránya 9\%. A SM diagnózisát MRI-vizsgálattal az esetek 96\%-ában erősítettük meg, míg liquorvizsgálat az esetek felében történt. A betegek döntő többsége immunmoduláns kezelésben részesült. Rendszeres neurológiai ellenőrzésen (évente legalább egy kontrollvizsgálaton) a betegek 80\%-a vett részt.

\section{Megbeszélés}

A hagyományos módszerrel (manuális adatbevitel) készült regiszterünkben 316 beteg adatai szerepelnek. A SM diagnózisát megbízhatónak tartjuk, mert 96\%-ban MRI-vizsgálatok támasztották alá. Mivel a SM diagnosztikai kritériumaiban ma már csak kiegészítő szerep jut a liquorvizsgálatnak, ezzel összhangban betegeink 45\%ánál történt ez meg, amely magasabb arány például az Amerikai Egyesült Államokban közöltnél (2010 és 2014 között 21,7\%) [8].

A regiszterben rögzített betegeink körében a nő : férfi arány 1,95 : 1, amely némileg alacsonyabb a Csongrád megyei adatnál [6]. Betegeink átlagos életkora 42 év, ez nem különbözik a férfiak és a nők körében. A primer progresszív kórlefolyást mutató páciensek aránya 9\%, ez a Csongrád megyei 6\%-os értéknél magasabb [6], és megfelel a nemzetközi arányoknak, ami 7,3\% és 11\% között változik [9]. Azonban míg a nők körében 5,7\%, addig a férfiak közt 16\% az előfordulása a betegeink között. A betegségtartam átlagosan 12,9 év volt, és ennek során a betegek $82 \%$-a részesült valamilyen immunmoduláns kezelésben, ami megegyezik a svájci regiszter mutatójá$\operatorname{val}(81,7 \%)[10]$.

A helyi SM-centrumok érdeke betegeinek folyamatos és a legfrissebb adatokat is tartalmazó nyilvántartása, ami kutatási és klinikai célokat is szolgál. Hazánkban a 2000es évek elejéig kötelező volt havonta jelentést küldeni az immunmoduláns kezelésben részesülő betegekről a Jahn Ferenc Kórház SM-centrumába, ez később megszakadt. A Magyar Neuroimmunológiai Társaság deklarált célja, hogy egységes és teljes körű országos SM-regiszter jöjjön létre, amelynek részletes kereteiről már zajlanak az egyeztetések. Az országos és nemzetközi adatbázisok egyik fó hozadéka az, hogy míg a multicentrikus randomizált kontrollált klinikai vizsgálatok a terápiás beavatkozások hatásosságáról („efficacy”) adnak információt, a sok éven át gyüjtött „real-life” adatok több tízezer betegen történő szisztematikus elemzése alkalmas lesz a különböző kezelési eljárások tényleges hatékonyságának („effectivity”) megítélésére is.
1. táblázat |A helyi SM-regiszter alapjellemzői

\begin{tabular}{|c|c|c|c|}
\hline Tényező & $\begin{array}{l}\text { Tervezett/várt } \\
\text { érték }\end{array}$ & Tény & Megjegyzés \\
\hline $\begin{array}{l}\text { Bevitt } \\
\text { betegszám }\end{array}$ & 300 & 316 & $\begin{array}{l}\text { A gondozás } \\
\text { megszakadhat }\end{array}$ \\
\hline MRI-lelet & $300(100 \%)$ & $307(96 \%)$ & $\begin{array}{l}\text { Átlag 4,7 } \\
\text { MRI/fö } \\
\text { (1446 db) }\end{array}$ \\
\hline Liquorlelet & $50 \%$ & $\begin{array}{l}145 \text { beteg } \\
(45 \%)\end{array}$ & \\
\hline $\begin{array}{l}\text { Terápiamodali- } \\
\text { tás }\end{array}$ & $100 \%$ & $100 \%$ & \\
\hline $\begin{array}{l}\text { Legalább } \\
\text { évente kontroll }\end{array}$ & $100 \%$ & $257(80 \%)$ & $\begin{array}{l}\text { „Túl rosszul” } \\
\text { és „túl jól” } \\
\text { levoók }\end{array}$ \\
\hline
\end{tabular}

MRI = mágnesesrezonancia-képalkotás; SM = sclerosis multiplex

2. táblázat |A helyi betegcsoport jellemzői

\begin{tabular}{llll}
\hline Változó & $\begin{array}{l}\text { Férfiak } \\
(\mathrm{n}=107)\end{array}$ & $\begin{array}{l}\text { Nók } \\
(\mathrm{n}=209)\end{array}$ & $\begin{array}{l}\text { Teljes csoport } \\
(\mathrm{n}=316)\end{array}$ \\
\hline $\begin{array}{l}\text { Életkor } \\
(\text { átlag } \pm \text { SD })\end{array}$ & $41,6 \pm 9,8$ & $42,2 \pm 10,9$ & $42,0 \pm 10,6$ \\
$\begin{array}{l}\text { Betegségtartam } \\
\text { a tünetkezdet- } \\
\text { tól (év, átlag } \pm\end{array}$ & $11,8 \pm 7,8$ & $13,4 \pm 8,3$ & $12,9 \pm 8,2$ \\
$\begin{array}{l}\text { SD) } \\
\text { Betegségkez- } \\
\text { det* } \\
(\text { CIS } / P P)\end{array}$ & $73 / 14$ & $165 / 10$ & $238 / 24$ \\
$\begin{array}{l}\text { Immunmodu- } \\
\text { láns kezelésben } \\
\text { részesült }(\%)\end{array}$ & $80 \%$ & $83 \%$ & $82 \%$ \\
\hline
\end{tabular}

CIS = klinikailag izolált szindróma; PP = primer progresszív kórforma; $\mathrm{SD}=$ standard deviáció

*A betegség kezdetéről 262 páciens esetében van pontos információnk.

A helyi SM-regiszterek létjogosultsága azonban gyakorlati szempontok miatt változatlanul fennáll. Korábban - elsősorban emberierőforrás-hiány és a technikai feltételek hiánya miatt - erre döntően egyszerü Exceltáblázatokat használtak, amelyek elsősorban a betegek azonosítását és terápiás csoportokba gyüjtését szolgálták, nem pedig klinikai állapotuk részletes követését. Ezt néhány centrumban (például a Szegedi Tudományegyetem Neurológiai Klinikáján [4]) már felváltotta egy webes alapú, részletesebb elemzést lehetővé tevő regiszter, ez azonban még nem vált általánossá.

A Szegeden vagy az általunk alkalmazott szoftver - a többi hasonlóval együtt - jelentős előrelépést jelent a helyi adatbázis-építés felé, de továbbra is nagy a humánerőforrás igényük, mert a legtöbb adatot manuálisan kell kikeresni és rögzíteni, folyamatosan vagy rendszeresen, hogy naprakészek maradjanak az információk. Ezeket a 
3. táblázat |A „hagyományos” helyi betegregiszterek jellemzőinek összefoglalása

\begin{tabular}{|c|c|c|}
\hline Belső & $\begin{array}{l}\text { Erősségek } \\
\text { - Tételenként kontrollált } \\
\text { adatbevitel } \\
\text { - A bevitt adatok közvetlen } \\
\text { ellenórzése a forrásdoku- } \\
\text { mentumokban } \\
\text { - Elvégezhető a hagyomá- } \\
\text { nyos informatikai háttér } \\
\text { alkalmazásával (például } \\
\text { Excel) } \\
\text { - Igény szerint kiegészíthető } \\
\text { új szempontokkal } \\
\text { - Rugalmas, bármikor } \\
\text { definiálható szempontok } \\
\text { szerinti leválogatás }\end{array}$ & $\begin{array}{l}\text { Gyengeségek } \\
\text { - Intenzív munkaerőigény } \\
\text { - Nem automatizálható } \\
\text { - Nem folyamatos } \\
\text { - Erôsen motivációfüggő } \\
\text { - Nem webalapú } \\
\text { - Lokális adattárolás miatt } \\
\text { az adat elveszhet }\end{array}$ \\
\hline Külső & $\begin{array}{l}\text { Lehetôségek } \\
\text { - Külső munkaerő bevonása } \\
\text { lehetséges (például } \\
\text { tudományos diákköri } \\
\text { hallgatók) }\end{array}$ & $\begin{array}{l}\text { Veszélyeztetô tényezők } \\
\text { - A megszűnő motiváció } \\
\text { az adatbázis töltését } \\
\text { veszélyezteti }\end{array}$ \\
\hline
\end{tabular}

SM-regisztereket „hagyományos” típus néven összefoglalva, elvégeztük a SWOT-elemzésüket (3. táblázat).

A helyi SM-adatbázis létrehozása (a jelen esetben a Semmelweis Egyetem Neurológiai Klinikáján) az első lépése annak a folyamatnak, amelynek távlati célja egy olyan helyi regiszter kifejlesztése, mely össze van hangolva a digitális betegnyilvántartási rendszer (jelenleg a MedSol) adataival. Ezen tervezett korszerú adatbázis folyamatábráját mutatjuk be a 2. ábrán, és SWOT-elemzését a 4. táblázatban.

A modell kidolgozásakor azt tartottuk szem előtt, hogy olyan informatikai rendszerre van igény, amelyben kiküszöbölhetók lesznek a „hagyományos” adatbázisokban jelentkező technikai problémák. Ilyen például a PDF formátumban történő adatforgalom, a betegdokumentáció nem egységes formátuma/tartalma, az intézményen belüli informatikai alrendszerek inkompatibilitása, a hardverhiba miatt történő adatvesztés stb. A korszerü regiszter jóval kevesebb kézi adatbevitelt igényel, mert a különböző adatforrásokból (állapotleírások, labor, képal-



2. ábra $\quad$ A korszerű helyi SM-regiszter folyamatábrája. Jellegzetes az automatizált online adatáramlás, betegségspecifikus interfész az online adatbevitelhez és adatkinyeréshez, illetve a folyamatos adatfrissülés 
Az új megközelítésű adatbázis-építés jellemzőinek összefoglalása

\begin{tabular}{|c|c|c|}
\hline Belső & $\begin{array}{l}\text { Erôsségek } \\
\text { - Automatikus és folyamatos } \\
\text { adatátvitel egyéb } \\
\text { rendszerekből } \\
\text { - A fejlesztést követően kis } \\
\text { emberierőforrás-igény } \\
\text { - Fenntartása kevésbé } \\
\text { motivációfüggö }\end{array}$ & $\begin{array}{l}\text { Gyengeségek } \\
\text { - Speciális szoftverfejlesztési } \\
\text { igény } \\
\text { - Erős informatikai háttér } \\
\text { kell } \\
\text { - A GDPR betartása } \\
\text { nehezebb az online } \\
\text { rendszer miatt }\end{array}$ \\
\hline Külsô & $\begin{array}{l}\text { Lehetőségek } \\
\text { - Gyakorlatilag korlátlan } \\
\text { mérethatár } \\
\text { - Közvetlen adatbevitel a } \\
\text { betegek részéról } \\
\text { - Országos/nemzetközi } \\
\text { regiszterekhez történő } \\
\text { online csatlakozás } \\
\text { kétirányú adatforgalommal }\end{array}$ & $\begin{array}{l}\text { Veszélyeztető tényezők } \\
\text { - Külső informatikai } \\
\text { támadások lehetősége } \\
\text { - Elektronikus rekordok } \\
\text { elvesztésének lehetősége } \\
\text { - Illetéktelen adathasználat }\end{array}$ \\
\hline
\end{tabular}

GDPR = európai általános adatvédelmi szabályzat

kotó) online, valós időben („real-time”) és automatikusan jutnak az információk a webalapú adatbázisba. A regiszter fó forrása az adatokat eredeti formátumban tároló úgynevezett adattó, ahová a betegellátás során keletkező információ (automatikusan) mentésre kerül, majd onnan utólag, újabb és újabb szempontok szerinti elemzésre könnyen előhívható. Megfelelő kontroll mellett lehetőség lesz a betegek részéról közvetlen adatbevitelre is a regiszterbe, és megoldható a helyi és a központi (országos és nemzetközi) adatbázisok közötti kétirányú adatáramlás. Megoldandó a személyes adatok védelmének biztosítása, és egyértelmúen rögzíteni kell a klinikai és kutatási célú adatfelhasználás elveit és szabályait. Az egészségügyi adattó hazai prototípusának kidolgozása és megvalósítása a Pécsi Tudományegyetem és az E-Group ICT Zrt. konzorciális együttmúködésével már folyamatban van (InnoHealth DataLake GINOP-2.2.1-152017-00067).

Anyagi támogatás: A tanulmány alapjául szolgáló kutatást az Emberi Erőforrások Minisztériuma által meghirdetett Felsőoktatási Intézményi Kiválósági Program támogatta, a Semmelweis Egyetem neurológiai tématerületi programja keretében, emellett a Semmelweis Egyetem Egészségügyi Közszolgálati Kar nyújtott anyagi támogatást.

Szerzői munkamegosztás: S. M., I. A., T. N.: Az adatbázis létrehozása. Sz. M., M. P., B. D.: A koncepció kidolgo- zása. B. D.: A statisztika elkészítése. B. D., I. A., S. M., T. N.: A kézirat megszövegezése és az ábrák elkészítése. A cikk végleges változatát valamennyi szerző elolvasta és jóváhagyta.

Érdekeltségek: A szerzőknek nincsenek érdekeltségeik a cikkel kapcsolatban.

\section{Köszönetnyilvánítás}

Köszönetünket fejezzük ki a Semmelweis Egyetem Egészségügyi Közszolgálati Karának az anyagi támogatásért.

\section{Irodalom}

[1] Feigin VL, Alemu Abajogir A, Hassen Abate K, et al, for GBD 2015 Neurological Disorders Collaborator Group. Global, regional, and national burden of neurological disorders during 1990-2015: a systematic analysis for the Global Burden of Disease Study 2015. Lancet Neurol. 2017; 16: 877-897.

[2] Gustavsson A, Svensson M, Jacobi F, et al. Cost of disorders of the brain in Europe 2010. Eur Neuropsychopharmacol. 2011; 21: 718-779.

[3] Iljicsov A, Simó M, Tegze N, et al. Databases in neurological diseases: overview of international examples in multiple sclerosis. [Nagy adatbázisok neurológiai kórképekben: nemzetközi áttekintés a sclerosis multiplex példáján.] Orv Hetil. 2019; 160: 123-130.

[4] Bencsik K, Sandi D, Biernacki T, et al. The Multiple Sclerosis Registry of Szeged. [A Szegedi Sclerosis Multiplex Regiszter.] Ideggyógy Sz. 2017; 70: 301-306. [Hungarian]

[5] Bencsik K, Rajda C, Klivényi P, et al. The prevalence of multiple sclerosis in the Hungarian city of Szeged. Acta Neurol Scand. 1998; 97: 315-319.

[6] Zsiros V, Fricska-Nagy Z, Füvesi J, et al. Prevalence of multiple sclerosis in Csongrád County, Hungary. Acta Neurol Scand. 2014; 130: 277-282

[7] Péntek M, Gulácsi L, Rózsa C, et al. Health status and cost of ambulatory patients with multiple sclerosis in Hungary. [Magyarországi sclerosis multiplexes járó betegek egészségi állapota és betegségköltsége.] Ideggyógy Sz. 2012; 65: 316-324. [English]

[8] Visaria J, Thomas N, Gu T, et al. Understanding the patient's journey in the diagnosis and treatment of multiple sclerosis in clinical practice. Clin Ther. 2018; 40: 926-939.

[9] Salter A, Thomas NP, Tyry T, et al. A contemporary profile of primary progressive multiple sclerosis participants from the NARCOMS Registry. Mult Scler. 2018; 24: 951-962.

[10] Disanto G, Benkert P, Lorscheider J, et al. The Swiss Multiple Sclerosis Cohort-study (SMSC): a prospective Swiss wide investigation of key phases in disease evolution and new treatment options. PLoS ONE 2016; 11: e0152347.

(Bereczki Dániel dr., Budapest, Balassa u. 6., 1083 e-mail: bereczki.daniel@med.semmelweis-univ.hu)

A cikk a Creative Commons Attribution 4.0 International License (https://creativecommons.org/licenses/by/4.0/) feltételei szerint publikált Open Access közlemény, melynek szellemében a cikk bármilyen médiumban szabadon felhasználható, megosztható és újraközölhető, feltéve, hogy az eredeti szerző és a közlés helye, illetve a CC License linkje és az esetlegesen végrehajtott módosítások feltüntetésre kerülnek. (SID_1) 